$2666 / 3$

American Philosophical Society

The Year Booly 1944, of the American Philo. sophical Socie covers the year January 1, 1944Decembor 1.1944. During the year a radical change was madin the policy of the Society's library towards xchange and distribution of the Society's puld cations, based on the conviction that acquisitions for the library and the distribution of the Society's publications can be more effectively promoted through subscriptions than by the system of exchange. Under the new policy, the library receives in exchange for the Society's publications relatively little, depending rather on subseription or direct purchase of materials vital to the development of its holdings. The Library Committee is also mindful of the possibilities of current trends in library and research disciplines like those started by Binkley and recently developed by Fremont Rider in his volume "The Scholar and the Future of the Research Library". The problem of bringing the rich resources of the library to the attention of scholars and making them available for study and research has been a major concern of the librarian. Two special committees were set up during the year to assist in this way, in the special fields of American linguistics and archæology and of Americana. Of exceptional interest in this Committee's report are the notes by C. Dan Doren on the Franklin-Mecon correspondence, by G. Chinard on the strange fortune of two volumes of the Transactions associated with Franklin, and on the Elihu Thomson collection. The report of the Committee on Research includes a list of grants made from the income of the Penrose Fund and a summary of the grants made during the period July 31, 1933December 31, 1944, together with reports from recipients of grants, arranged alphabetically under the classification of subjects represented in the membership of the Society. Because of the participation of many scientific men in research connected with the war effort, particularly in certain fields, the request for grants dur ing the past two years was not as large as previously, but the Committee has not lowengd the standard set for making grants.

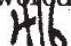

Natidnal Foundation for Scientific Research, Brussels

THE seventh annual report of the National Foundotion or Scientific Research, Brussels, for the year $194{ }^{4} 4$ in addition to the report on the activitiep of Foundation during the year, includes the stat tes, a list of members of the scientific commission and of publications during the year, which renders the report a most useful reference work. Reporting on eleven important projects in the field of industrial science, reference is made to research financed by the Foundation André van der Stricht on the mechanism of the degradation of nitrogenous substances contained in yeasts, malts and moulds of breweries. The Etablissements Hauzeur, Simonis and Peltzer have financed a research on the physicochemical affinity between the molecules of certain colouring matters and proteins, especially the keratins of wool. Further research is being assisted by the Fabrique de Produits Chimiques de Grammont on the preparation, improvement and stabilization of certain grades of animal black and of certain carbons and colloids constituting the active absorbents. The Belgian Institute for the Improvement of the Beet is supporting an experimental study of the causal factors of the phenomena of polyploidy in the beet, in view of its eventual systematic use
August 24, 1946 vol. 158

in industrial cultivation. The Belgian Association for the Testing and Use of Materials is supporting an investigation on the protection of ferrous metals against corrosion, and the Optical Society of Belgium an investigation leading to the development of a photometer for the trichromatic specification of colour.

\section{Cheshunt Research Station}

THE glasshor work of the Experimental and Research Sndon at Turner's Hill, Cheshunt, Herts, was inferr pted by enemy action in July 1944 ; but a Mbst int 1 amount of laboratory work was carried ou during that year (Rep. Exp. Res. Sta., Cheshunt, 1944). Preliminary trials by W. H. Read show that 5 per cent D.D.T./kaolin dusts or 0.02 per cent D.D.T. sprays give good control of tomato moth caterpillars (Polia oleracea). Red spider mites are not, however, controlled by this new insecticide, but D.D.T. can be added to petroleum emulsion sprays and the mixture used for the control of both pests. E. R. Speyer and W. J. Parr suggest measures for the control of tomato leaf-miners (Liriomyza spp.). These involve steaming the soil of propagating houses before introduction of the staging, and growing plants with a harder kind of growth than normal. Magnesium deficiency of tomato has been studied by $O$. Owen, who finds that spraying the foliage with 2 per cent Epsom salts, plus a wetting agent, gives good control. I. W. Selman finds that Cheshunt Early Giant lettuce is most resistant to mosaic virus when grown with low nitrogen and low phosphate, with medium watering. It is unlikely, according to $\mathrm{P}$. H. Williams, that Verticillium wilt can be controlled by altering the $p H$ of the soil, as the fungus can grow well between $p H 4.0$ and $8 \cdot 0$. A severe loss of heliotrope cuttings, due to the fungus Corticium solani, is described by Mrs. E. Sheard. The report of the director (Dr. W. F. Bewley) shows that experiments on the growth of tomatoes in gravel cultures have been commenced. Trials of bulky composts were inconclusive because of damage by enemy action.

\section{London Scient fic F.Im Society}

The London Scientific Film Society, 34 Soho Square, Lon/on, W.1, which has been re-organised and enlarged, starts its ninth season in September. It has booled the Scala Theatre in Charlotte Street, London for ten Sundays in the next ten months, and will slow programmes of scientific and documentary film afternoon and evening. In addition it hopes to aryange for lectures and showings of research films on weekday evenings in suitable halls. It also proposes activities to organise shows of scientific films for children and to publish a small quarterly journal to be called the Scientific Film. The Society is also to sponsor the production of experimental films by a group of its members. Membership is open to anyone more than sixteen years old.

\section{Size of Page lip Technical Journals}

A Report of the Technical and Trade Papers Commiftery the Institute of Incorporated Practitiomrs If Advertising to the Trade and Technical Prose dated October 1943, was issued in May 1946 by the Institute under the title "Standardisation Wf Type Area Sizes for Trade and Technical Journals", with the note that the trade and technical Press has recommended its members to give serious consideration to the standardization of type-areas. The members of the Institute hope that British 